\title{
Empreendedorismo como ferramenta de desenvolvimento econômico e geração de emprego e renda: elaboração de metodologia para criação de micro e pequenas empresas
}

Recebido em 14.08.2015. Aprovado em 20.11.2016 Avaliado pelo sistema double blind review

\author{
Antonio Tavares Costa \\ ratcosta@gmail.com \\ Universidade Federal do Amapá - Macapá - AP
}

\begin{abstract}
Resumo
Este artigo teve como objetivo a criação de uma metodologia de enfrentamento de crise com base no empreendedorismo e criação de arranjos produtivos locais, tal metodologia concerne em padronização para qualquer atividade produtiva. No cenário econômico mundial estamos vivendo um período de crise econômica com baixo crescimento dos países e o esgotamento dos mercados consumidores. Na pesquisa foram abordados temas como empregabilidade, empreendedorismo, Arranjo Produtivo Local e jogos de empresas, para consolidação de tal metodologia e principalmente buscou-se com ela, verificar se os jogos de empresas são uma ferramenta importante na formação de características empreendedoras relevantes nos jovens universitários. Por tanto, este artigo busca a elaboração de uma metodologia voltada à formação de empreendedores com foco na criação de Arranjos Produtivos Locais e geração de emprego e renda, visando 0 enfrentamento de crises econômicas e financeiras regionais, com base em jogos de empresas simulados, como parte integrante de projetos de políticas pública.
\end{abstract}

Palavras-chaves: Micro e Pequenas Empresas. Empreendedorismo. Arranjo Produtivo Local. Jogos de Empresas.

\begin{abstract}
This article aims at creating a methodology for coping with crisis based on entrepreneurship and creating local clusters, such methodology standardization in relation to any productive activity. In the global economy we are living in a period of economic crisis with low growth countries and depletion consumer markets. On research topics such as employability, entrepreneurship, Local Productive Arrangement and games companies to consolidate such methodology and especially sought with it, check whether the games business are an important tool in the training of relevant entrepreneurial characteristics in young university students were approached . Therefore, this paper seeks the development of a methodology aimed at the training of entrepreneurs with a focus on the creation of Local Production and generation of income and employment, aiming at coping with economic and regional financial crises, based on simulated games companies, as integral part of public policy projects.
\end{abstract}

Keywords: Employability. Entrepreneurship. Local Productive Arrangement. Business Games. 


\section{Introdução}

O mundo vem passando por um momento de transformação intensa, o ambiente mercadológico está cada dia mais competitivo e as empresas necessitam ajustar-se a este mercado para não serem extintas, porém a evolução nas empresas só acontecerá se os encarregados de gestão assim o fizerem, estas pessoas precisam participar de treinamentos gerenciais que desenvolvam as habilidades e competências essenciais para a atual gestão empresarial exigida por este mercado. Segundo Mendes (1997, p.05), "as empresas vêm passando por um grande processo de transformação e evolução, porém os indivíduos precisam evoluir para acompanhar estas empresas", assim se verifica a necessidade de criação de mecanismos experimentais para mensurar 0 potencial do empreendedor, e por meio destas ferramentas identificar pontos fortes e pontos fracos para desenvolver atividades focadas a cada participante de treinamento empresarial.

Neste contexto surgem os treinamentos empresariais, ferramenta muito usada em cursos de executivos e em salas de aula de cursos de administração e áreas afins, com o objetivo de ensinar o funcionamento do mundo dos negócios e como tomar decisões em situações reais de mercado.

Os treinamentos simulados se desenvolvem por meio de um ambiente empresarial teórico contendo cenários mercadológicos, buscando tomadas de decisões rápidas e precisas, o que é de extrema necessidade para introduzir um futuro empreendedor no mundo dos negócios. Segundo Santos (2003), os treinamentos simulados possibilitam que sejam desenvolvidos em laboratórios cenários que muitas vezes na prática são de difícil formulação, pelas consequências que uma atitude tomada erradamente possa causar, proporcionando assim aos participantes destes treinamentos experiências novas. Eles podem, assim, ser utilizados como uma ferramenta adicional na fixação do aprendizado organizacional.

Contudo verificamos a necessidade de desenvolver ferramentas que integrem várias formas de construtivismo organizacional para formar empreendedores e prepará-los para este mercado competitivo. Neste sentido a nossa proposta neste artigo é a criação de uma metodologia focada no desenvolvimento cognitivo e pragmático do empreendedor por meio da junção de atividades em parcerias público/privadas sendo estas atividades de pesquisa, extensão e ações empresariais que possibilitam a estes administradores o desenvolvimento de habilidades e competências gerenciais empreendedoras, deixando para traz os treinamentos tradicionais e colocando em prática uma nova metodologia de ensino e aprendizagem.

A figura do empreendedorismo esta cada vez sendo mais explorada nas pesquisas da área empresarial, porém os pesquisadores conceituam como empreendedores as pessoas que têm qualidades subjetivas como; saber trabalhar em equipe, ser visionário, correr riscos calculados, ocultando por muitas vezes que o empreendedor deve ser sim a pessoa que têm técnicas empresariais, pois, se este administrador não tiver conhecimentos sobre plano de negócios, elaboração de preço de venda de produtos, gestão de cargos e salários, relatórios financeiros, este empreendedor nunca conseguirá com suas habilidades e competências fictícias ou "utópicas" manter sua empresa no mercado.

Contudo, as pesquisas sobre empreendedorismo relatam estes indivíduos como pessoas que conseguem ver oportunidade onde os outros não conseguem, e ainda estas pesquisas insistem em afirmar que estes trazem estas características de nascimento, ou que estes são seres humanos diferentes dos outros, e isso é evidenciado em várias pesquisas de mestrado e doutorado. Todavia se ser empreendedor é um adjetivo adquirido de forma "genética" ou por "mágica" os empreendedores não necessitariam de mais nada para serem bem sucedidos. Esta metodologia tem por objetivo desenvolver estas características empreendedoras nos participantes e ainda acompanhar por meio de encubação de empresas o nascimento e desenvolvimento das micro e pequenas indústrias abertas e ainda gerar emprego e fazer por meio dos acadêmicos bolsistas a orientação empresarial e por meio de professores universitários parceiros a consultoria empresarial nestas empresas. Assim com a metodologia proposta tais ferramentas desenvolvidas servirão de base na formação de habilidades e competências gerenciais necessárias para o desenvolvimento e manutenção de uma empresa no atual contexto mercadológico.

Os estudos da área de recursos humanos atribuem o desenvolvimento de habilidades e competências aos treinamentos gerenciais e afirmam ainda que para que estes sejam bem sucedidos devem ser desenvolvidos 
de forma precisa e dinâmica, para que elas fixem em sua forma de pensar uma contextualização prática e mercadológica.

Os treinamentos empresariais promovem uma interação entre o aprendizado nas dimensões afetiva e cognitiva, proporcionando uma absorção do conhecimento pleno, tratando a pessoa que participa deste treinamento como um ser racional e emocional. $\mathrm{O}$ uso de treinamentos empresariais permite uma visão multidisciplinar, dando oportunidade ao aluno de desenvolver uma visão holística da estrutura organizacional.

Segundo, Keys e Wolfe apud Orlandeli (2001, p.05), em trabalho desenvolvido por meio da avaliação da aplicação de treinamentos simulados no processo de ensino em universidades dos Estados Unidos, há vantagens no uso destes; entre elas a maior fixação dos conceitos apresentados no treinamento, quando comparados com aplicação de estudos de caso e com métodos tradicionais de ensino, como aulas expositivas, usados isoladamente. Outras vantagens também se destacam no ensino da Administração geral e, alegadamente, no desenvolvimento futuro da vida profissional dos indivíduos que se envolvem nesses processos de aprendizagem.

Por isso o desenvolvimento desta metodologia é de fundamental importância para a criação de novas micro e pequenas industrias e ainda no longo prazo na criação de Arranjos Produtivos Locais "APL" por meio do desenvolvimento de uma nova cadeia produtiva, orientada e criada de forma organizada, o que no futuro poderá ser base para criação de políticas públicas visando o desenvolvimento regional.

\section{Metodologia}

A evolução do cenário mercadológico global fez surgir à necessidade de criar metodologias capazes de desenvolver o crescimento econômico, por meio de geração de emprego e renda, sendo assim surge a necessidade da quebra do paradigma do empreendedor somente por "nascitura" ou "nato" fazendo surgir outras possibilidades de criação de empreendedores. Seguindo este pensamento elaboramos tal metodologia pautada no desenvolvimento das características empreendedoras dos empresários e novos empresários. Esta roupagem se referencia a capacidade de empreendedores de sucesso de atribuir a seus comportamentos e não a fatores externos, as causas de seus êxitos ou fracassos.

Por tanto, a metodologia estará voltado para o desenvolvimento de comportamentos, ou seja, toda a filosofia em questão esta focada para a internalidade do empreendedor. Desta forma tende-se a objetivar primeiramente o novo comportamento do participante voltado ao desenvolvimento da auto-responsabilidade e a influência desta em relação as suas realizações em qualquer nível. Ainda se busca o aprofundamento da questão ensino/aprendizagem, onde se acredita que este processo só estará concluído se houver mudança nas ações do participante.

Para isso o desenvolvimento da metodologia está dividida em 5 (cinco) fases:

- A primeira onde será criado o comitê gestor do programa contendo como atores Universidades, iniciativa privada e Entes públicos, ambos devem ter interesses comuns no desenvolvimento do Arranjo Produtivo Local;

- A segunda fase é o processo de seleção via edital público dos bolsistas que participarão do programa assim como das empresas que serão encubadas;

- A terceira fase é o processo de capacitação dos bolsistas "Formação de consultor Júnior" e "Metodologia de formação de empreendedores" e dos empresários aprovados no processo seletivo para encubação "Metodologia de formação de empreendedores";

- A quarta fase é o processo de financiamento das empresas encubadas e encubação das empresas, com acompanhamento personalizado do consultor júnior "aluno bolsista", cada um será responsabilizado pelo acompanhamento da gestão de cada empresa encubada; 
- A quinta fase é a criação do Arranjo Produtivo Local por meio da inclusão das novas indústrias de pequeno porte. Onde ocorrerá ainda a criação de centro de dados para compartilhamento de conhecimento e informação qualificada sobre o território abrangido pelo APL, avaliando constantemente seus vetores sociais, políticos, econômicos, ambientais e culturais; Fortalecimento de articulação de rede de cooperação público-privada; Organização Produtiva de setores prioritários e promoção de capacitação e nível de serviço; Criação de ambiente de negócios favoráveis baseado em boas práticas e suporte de programas específico voltados para o Desenvolvimento Local e financiamento diferenciado; Criação de rede de agentes gestores de apoio e desenvolvimento do APL; Criação de ações integradas de APL como busca de financiamento, compra conjunta, comunicação, dentre outas; Realização de fórum anual para realização de balanço de ações, projeção de cenários; identificação de potencialidades, oportunidades, lideranças, ameaças, dentre outras.

Portanto, a metodologia está divida em fases onde cada uma tem sua funcionalidade muito bem definida. A fase de treinamento é desenvolvida com base em ciclos de aprendizagem com uso de dinâmicas de grupo com abordagem internalizada, textos e debates diários e um jogo de empresa desenvolvido exclusivamente para atender o Arranjo Produtivo Local específico à cada edital, que geram tarefas que são cobradas todos os dias do curso, tendo como foco a aprendizagem para o aqui e agora. Há ainda os ciclos de discussões dos dias anteriores focando seus principais pontos, faz parte ainda do treinamento os mecanismos de gestão como: fluxo de caixa, formação do preço de venda, planejamento estratégico, além de fontes de financiamento bancários.

A metodologia sugerida para ter sucesso na sua aplicação terá de contar com uma equipe de instrutores comprometidos e qualificados. Para fazer parte deste quadro em um primeiro momento o profissional precisa participar de um concurso público "edital" que tem como critério a avaliação curricular e banca examinadora com pontos especificamente voltados ao projeto. Após a aprovação do candidato ele precisa participar da oficina de formação de instrutores como aluno e será avaliado pelos coordenadores do programa, mediante sua pontuação geral, caso positiva este candidato ainda deverá participar do curso de repasse da metodologia.

Com o repasse esse profissional será acompanhado em um primeiro curso pelo coordenador do programa em sua primeira turma, este coordenador responsável pelo acompanhamento será denominado consultor educacional, será avaliado como instrutor treinee e esta fase ainda faz parte da avaliação do instrutor que só terá autonomia a partir do seu segundo curso, caso seja aprovado nesta fase. Esse critério é um dos pontos do processo de qualidade da metodologia.

0 treinamento conta com conteúdo moderno e dinâmico, são 08 (oito) módulos elaborados buscando como foco as 10 (dez) CCE's, para melhor mensurar a reação dos participantes e visando a absorção do conteúdo. A metodologia é dividida em 3 (três) fases: realização (busca de oportunidade e iniciativa; persistência; correr riscos calculados; comprometimento; exigência de qualidade e eficiência); planejamento (planejamento e monitoramento sistemático, busca de informações e estabelecimento de metas) e; poder (persuasão e rede de contatos, independência e autoconfiança), este conteúdo é sempre atualizados mediante o feedback dos que deles participam, a tabela a seguir demonstra a sistemática dos 08 (oito) módulos.

\begin{tabular}{|l|l|l|}
\hline$N^{\circ}$ & Módulos & Dia \\
\hline 1 & Abertura/Expectativas e Estabelecimento de metas & 01 \\
\hline 2 & Busca de Oportunidades e Correr riscos calculados & 02 \\
\hline 3 & Exercícios, Dinâmicas e Vivencias & \multirow{2}{*}{$03 / 04 / 05$} \\
\hline 4 & $\begin{array}{l}\text { Estudando e Desenvolvendo as Principais Características } \\
\text { empreendedoras de sucesso }\end{array}$ & \\
\hline
\end{tabular}


Empreendedorismo como ferramenta de desenvolvimento econômico e geração de emprego e renda: elaboração de metodologia para criação de micro e pequenas empresas

\begin{tabular}{|l|l|l|}
\hline 05 & $\begin{array}{l}\text { Estudando as principais ferramentas de gestão empresarial } \\
\text { e simulação de jogo empresarial }\end{array}$ & $\begin{array}{l}\text { 06/07/08/09/10/11/12/13/14/15 } \\
16 / 17 / 18 / 19 / 20\end{array}$ \\
\hline 06 & Estudando Arranjo Produtivo Locais & $21 / 22 / 23 / 24$ \\
\hline 07 & Montando meu empreendimento & $25 / 26 / 27 / 28 / 29$ \\
\hline 08 & $\begin{array}{l}\text { Estudando a filosofia de encubação de empresas e } \\
\text { Encerramento do seminário }\end{array}$ & \\
\hline
\end{tabular}

Quadro 1: Treinamento de formação de empreendedores com base em jogos de empresas simulados Fonte: Elaborado Pelo Autor

A figura a seguir demonstra o fluxo de processo da metodologia.

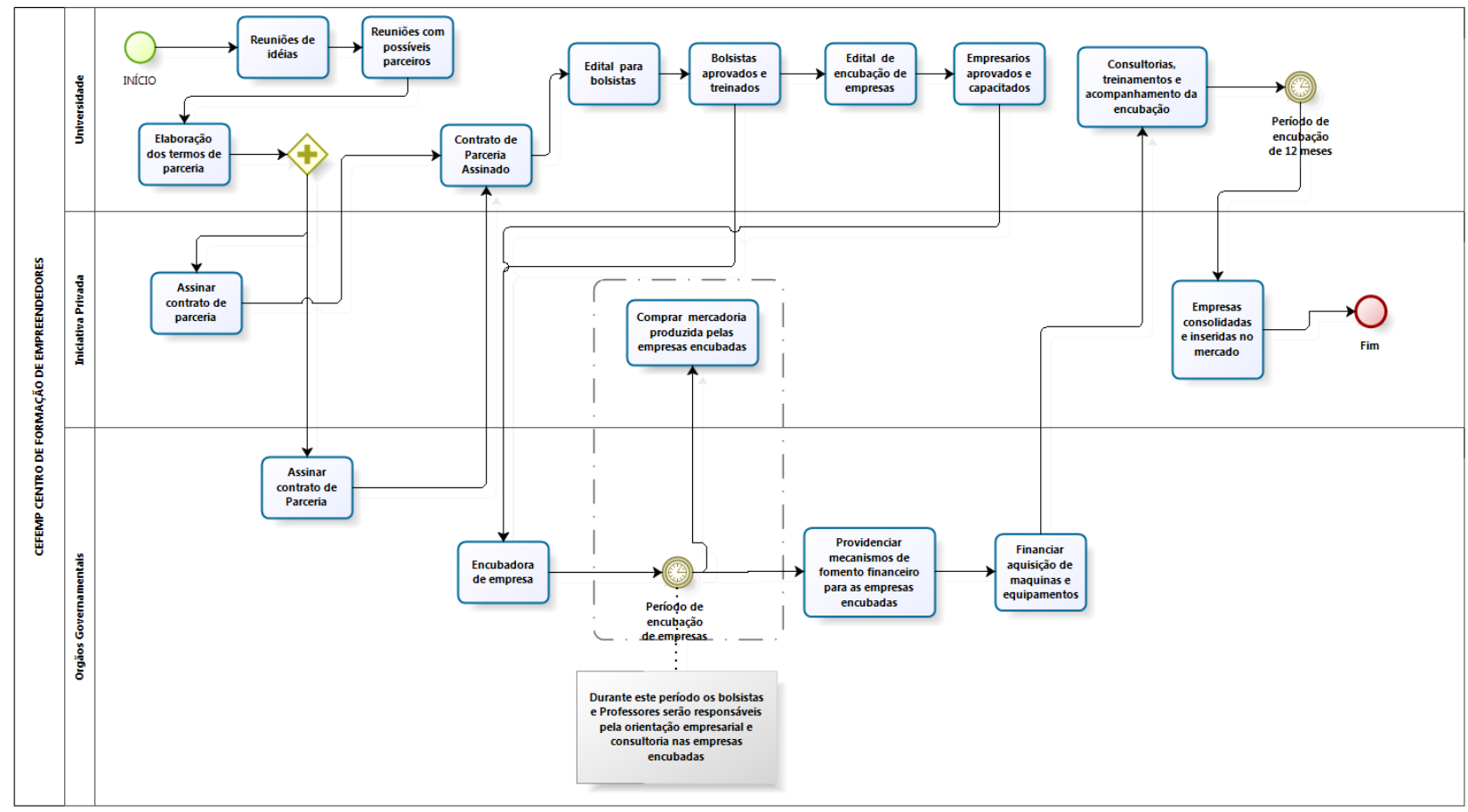

Figura 1: Fluxo Descritivo da Metodologia.

Fonte: Elaborado pelo autor.

\section{Fundamentação teórica}

Competências empreendedoras necessárias para o sucesso em arranjo produtivo local

Em um cenário mercadológico de alta competitividade, as empresas buscam a todo custo elevar a qualidade do gestor, preparando-os para realizar as ações de hoje e se antever as situações futuras. Desse modo, a gestão das competências compõe a gestão estratégica das pessoas em um ambiente de competição, como sendo uma forma inovadora e inteligente de satisfazer demandas dos ambientes organizacionais, visando manter-se no mercado ou adentrar em outros.

Nesse jogo, as empresas necessitam compreender as estratégias que a concorrência utiliza no mercado e ao mesmo tempo criar as suas próprias estratégias para vencer a disputa pela permanência no mesmo. De acordo com Castro, Rosental e Araújo (2007, p.38), as organizações perceberam que construir e operar com sucesso 
a empresa do futuro depende de capacitação de seu gestor. Não basta investir em recursos financeiros, em programas prontos e generalizantes: é preciso questionar e repensar a própria empresa e seus processos, envolvendo todos os agentes interessados em desenhar seu próprio caminho.

Assim, as empresas têm de se ajustar aos novos tempos, caracterizados pela competição e concorrência do mercado local em escala mundial. Tal fator se dá principalmente em decorrência da expansão tecnológica que aproxima os mercados em nível global e interferem no modo de operar e produzir mercadorias e serviços, sob o risco de não mais se manter competitiva e ser eliminada pela concorrência.

Na visão de Stewart (1998), diante da revolução em que a sociedade vive, é impossível prever com certeza que novas formas de trabalho e prosperidade irão surgir, pois tudo é surpresa. A única coisa previsível é que 0 sucesso de uma economia baseada na competência organizacional através do conhecimento, habilidades e atitudes para chegar a novos tipos de organizações e gerenciamento voltado para as pessoas com visão empreendedora que buscam desenvolver sua capacidade de resolver as situações surpresas de forma positiva.

0 autor reforça ainda, que o conhecimento torna-se um ativo valioso, quando este empreendedor cria uma ordem útil a partir da capacidade intelectual geral, o conhecimento permite ser descrito, compartilhado e explorado entre todos os elementos de uma empresa para construção de habilidades e atitudes que elevem as competências desenvolvidas a partir da troca de experiências entre os membros da organização. As competências estão associadas as habilidades que um indivíduo possui em determinadas atividades. Todo indivíduo possui competências, porém, alguns desenvolvem e outros não, significando que cada um em sua essência procura ou não aperfeiçoá-la.

Para Maria H. Araújo e Rochel M Lago (2005, p. 36) competência está associada a fazer algo bem feito, estamos vinculando esse conceito às ideias de ação e de resultado (...) seguindo este raciocínio, a competência está relacionada com o desempenho, com o comportamento de alguém e com a qualidade desse desempenho.

Ainda aos mesmos autores (2008, p. 49)... para se discutir competência para um determinado termo, como por exemplo empreendedorismo, deve-se diagnosticar o que precisam saber, saber fazer e saber ser, levando-se em conta que tais saberes deverão dar suporte às competências organizacionais para que elas possam concretizar-se.

Portanto, uma habilidade é um talento desenvolvido. É um potencial no qual você investe, treina, aperfeiçoa, e encontra uma aplicação prática e de reconhecido valor. Sendo assim, o talento é à base de nossas habilidades, mas só ganha importância em nossos resultados se existe um investimento planejado para seu desenvolvimento e utilização.

Como desenvolver as habilidades? A base para se desenvolver as habilidades está na identificação de talentos. Voltar o foco para muito bem, retreinar seus instintos e percepções. Se determinado indivíduo é bom em uma disciplina ou assunto, terá que investir mais tempo em estudos para o assunto.

As pessoas expressam seu conhecimento através da habilidade, da atitude, enfim de suas competências. A palavra competência foi primeiramente utilizada na idade média para definir aqueles que nos tribunais, tinham o conhecimento para apreciar e julgar determinadas questões. Ao longo do tempo passou a qualificar a pessoa que tem condições de realizar determinada atividade. Desde Taylor, ser competente tornou-se um grande diferencial no mercado de trabalho. Naquela época, competência estava mais relacionada à habilidade técnica, ou seja, saber fazer algo bem feito.

Com as constantes evoluções na Administração, competência passou a ser não só mais o saber fazer, mas saber por que fazer.

As competências possuem três dimensões:

1. Conhecimento é o único diferencial competitivo que não pode ser copiado ou imitado, pois as ações dele decorrentes são fruto da combinação entre o próprio conhecimento e o talento pessoal.

2. Habilidade talento de transformar o conhecimento adquirido em ações práticas que resultem numa melhoria de desempenho. 
3. Atitude dos três pilares da competência a atitude é a única que é inata e pessoal. Não depende de conhecimento nem de habilidade. As pessoas são o que são, pela sua história, caráter e valores pessoais.

A competência também se divide em dois tipos:

Competência pessoal e Competência Organizacional.

1. Competência Pessoal está relacionada aos conhecimentos e habilidades que o indivíduo possui, agregados ao nível de prontidão, a atitude.

2. Competência Organizacional está relacionada ao que de fato certa organização possui. Depende dos níveis de competência das pessoas, da gestão dos processos e da tecnologia aplicada.

A junção destas duas vertentes é o que de fato fará a grande diferença para o desenvolvimento do perfil do empreendedor ao mercado empresarial.

Desse modo, torna-se fundamental que as pessoas tenham oportunidades de novas aprendizagens para se tornarem capazes de criar mecanismos, desenvolverem ferramentas, inovar nas técnicas e ter novas ideias para construir conhecimentos e habilidades que levem o empreendedor ao sucesso. Nesse sentido, Amaral e Vilarinho $(2007$, p.35) destacam que:

[...] A aprendizagem torna-se um valioso instrumento a serviço do trabalhador, no processo de criação e inovação, e não se restringe aos sistemas escolares; tampouco, é privilégio dos sistemas formais de ensino. Ela perpassa toda a trajetória de vida e acontece em qualquer espaço, inclusive no ambiente de trabalho.

Compreende-se que o perfil empreendedor exigido pelo cenário mercadológico privilegia a criatividade, a interatividade, a flexibilidade e o aprendizado contínuo. $O$ indivíduo deve construir conhecimentos relacionados às suas aptidões e vivências culturais na busca de um melhor desempenho e maior eficiência em torno de novas e modernas atividades para alcançar sucesso nos resultados. Logo, competência torna-se "o conjunto de conhecimentos, habilidades, comportamentos e aptidões que possibilitam maior probabilidade de obtenção de sucesso na execução de determinadas atividades" (FAGUNDES, 2000, p.06).

Apesar da nova realidade, muitos empreendedores ainda não estão preparados para novos processos e resistem à mudança, além de que, temem que quanto mais preparados, mais acirrada a briga pela fatia do mercado. Assim sendo, a forma de desenvolvimento das competências, o instrumento utilizado para preparar esses empreendedores para serem atores efetivos e interagir nessa nova realidade, são desafios dos novos tempos para as empresas e tem de ser assimilado e processado pela educação corporativa a fim de se obter as respostas necessárias ao crescimento e desenvolvimento das empresas. Na visão de Castro, Rosental e Araújo (2007, p.38);

A capacitação das pessoas é um dos fatores críticos de sucesso para a sobrevivência das empresas nestes novos tempos. Transformar pessoas em proativas, que possam ousar, correr riscos calculados, buscar soluções para antigos problemas e ter disponibilidade para o aprendizado contínuo é o grande desafio de um novo mercado que está surgindo.

Segundo Novick (2007) "podemos não ser competentes em tudo o tempo todo, mas podemos desenvolver habilidades para aquilo em que não somos ainda competentes. As habilidades dão vida às competências". Diante do exposto, pode-se inferir que o indivíduo é competente quando ele busca, adquire e utiliza conhecimentos para realizar bem determinada tarefa, ou seja, deve ter e saber utilizar as habilidades desenvolvidas ao longo de sua vida pela aprendizagem e pela experiência, para resolver uma situação complexa.

De acordo com Bordoni (2008), as habilidades estão relacionadas à ação e dependem de conhecimentos, enquanto que as competências pressupõem aplicação das habilidades através de operações mentais, e do emprego de atitudes adequadas à realização de tarefas e à aquisição de conhecimentos. De acordo com a autora, as habilidades estão relacionadas ao "saber fazer" e competências ao "saber em ação". 
Desse modo, não basta ter o conhecimento e saber como se faz algo. Para ser competente, é necessário que de posse de determinadas habilidades a pessoa seja capaz de colocá-las em prática a qualquer momento de sua jornada para solução concreta de problemas e situações.

Para Novick (2007) a atividade laboral produtiva depende de novos conhecimentos para que se possa atuar de forma criativa, crítica e pensante, objetivando agir e se adaptar rapidamente às mudanças que ocorrem, não apenas no cenário mercadológico, mas em todas as esferas da sociedade, porém, o conhecimento por si só não representa competência, é necessário utilizar o conhecimento nas tomadas de decisão. É nesse contexto que as competências técnicas dos empreendedores deverão estar associadas à capacidade de decisão e de adaptação às novas situações que ocorrem no processo de competição e é externa a vontade da empresa.

\section{Processo ensino/aprendizagem na formação de competências empreendedoras}

Determinados educadores definem 0 ato de ensinar como, dirigir tecnicamente 0 aprendizado, concluindo que a arte de ensinar tem como resultado o processo de aprender. Deste modo, se o professor ensina, e o aluno não aprende, o processo não ocorreu, deixando como única alternativa reformular as técnicas de ensino. Segundo Ferreira (2000, p.62), "educação é uma palavra que diz respeito tanto ao processo de ensinar quanto aos resultados que são obtidos neste processo. Já a aprendizagem significa adquirir uma nova forma de conduta ou modificar uma conduta anterior".

Para Ferreira (2000, p.62), aprendizagem é o "processo pelo qual a educação se realiza (sic) isto é o processo de aquisição de hábitos de ação ou hábitos operativos". Em Sauaia (1997, p.14), a aprendizagem vivencial trabalha simultaneamente três importantes aspectos: "aprendizagem cognitiva, desenvolvimento de habilidades técnicas e comportamentais, e finalmente a transdisciplinaridade".

Assim, podemos verificar que é unânime, na opinião de profissionais da área de educação, que o processo de aprendizagem precisa motivar os alunos para as atividades. $O$ ensino tradicional (aluno, quadro negro, professor) vem sendo contestado e necessita passar por mudanças. Cada vez mais, se exige dos educadores novas formas de difusão do conhecimento. Os alunos, com os novos meios de comunicação, estão cada dia mais conscientes do seu propósito educacional, forçando estes docentes a utilizar novas tecnologias (videogame, computadores e sites da internet). Contudo, ensinar para pessoas sem experiência mercadológica que acabaram de adentrar a Universidade é tarefa difícil.

Para referendar o assunto abordado citaremos estudos de Robert F. Mager na área de Psicologia Educacional citados por Pessôa e Filho (2001, p.140), onde eles determinam três categorias de aprendizagem, às quais 0 professor deve dar prioridade para que o objetivo seja alcançado. Primeiro, "o aluno deve absorver o conteúdo cognitivamente ou dentro do campo do conhecimento, segundo, este aluno deve ainda modificar a forma de agir, pensar transformando suas atitudes mediante o conhecimento absorvido e por fim deve absorver novas habilidades".

No âmbito comportamental, Pessôa e Filho (2001, p.140), discriminam os diferentes níveis de aprendizado identificados por Fela Moscovici:

- Nível cognitivo (informações, conhecimentos, compreensão intelectual);

- Nível emocional (emoções e sentimentos, gostos, preferências);

- Nível atitudinal (percepções, conhecimentos, emoções e predisposição para ação integrada);

- Nível comportamental (atuação, e competência).

Assim, a autora argumenta que o processo psicoterapêutico aborda os níveis emocional e cognitivo por meio de trabalhos em laboratório que englobam não só a atividade mental, como também a afetiva.

No que se refere à aprendizagem vivencial ou prática, segundo Gramigna (1993, p.11), a vivência seria a atividade inicial ou o jogo de empresas propriamente dito; existindo ainda o relato, que é a parte em que os participantes contam suas experiências e compartilham seus sentimentos; o processamento, que é a fase na 
qual os participantes analisam os fatos ocorridos no treinamento; a generalização, na qual o grupo faz suas analogias ao mundo mercadológico real; e a aplicação, que é o fechamento do processo.

Desse modo é observado que ensinar não é um simples processo, mas sim um conjunto de atividades que exige: planejamento, orientação e controle das atividades do participante do treinamento.

$\mathrm{Na}$ área de estudos técnicos fazem-se necessárias novas tecnologias de ensino que atraiam a atenção destes participantes, e os mostre na prática mercadológica como as teorias são aplicadas. Um exemplo de prática simulada são os treinamentos empresariais, que tem sua avaliação baseada na teoria do aprendizado experimental, e traz um impacto positivo no decorrer do processo, já que este pode ser estruturado, segundo Orlandeli (2001, p.04), principalmente, de modo a "desenvolver e estimular o emocional, propondo respostas rápidas e precisas, de modo seguro, dando aos participantes uma visão global de uma organização e ainda fazendo com que aflore nos participantes um instinto competidor".

Segundo Lopes (2002, p.04-05), o treinamento de negócio computadorizado pode ser utilizado na formação de profissionais, e dando destaque aos níveis de especialização, essa afirmação é baseada na efetividade desta metodologia cognitiva para desenvolver habilidades importantes na área de administração de empresas. Hoffmann (207, p.13), afirma que esta ferramenta envolve funções culturais, conceituando jogos de empresas como:

(...) uma atividade ou ocupação voluntária, exercida dentro de certos e determinados limites de tempo e de espaço, seguida de regras livremente consentidas, mas absolutamente obrigatórias dotadas de um fim em si mesmo acompanhado de um sentimento de tensão e de alegria, com uma consciência de ser diferente da vida cotidiana.

Logo ensinar usando treinamento empresarial seria envolver as pessoas em simulações que englobam fatores da vida real do contexto empresarial, dando a oportunidade para que elas possam interagir em grupo e adquirir conhecimentos simultâneos e coletivos, tornando este tipo de treinamento uma ferramenta primordial no ensino da gestão empresarial.

Segundo Lopes (2002, p.04-05), "o treinamento de negócios ou simulação (multimídia ou vivencia) é de fácil acessibilidade, principalmente nos polos universitários, por isso se faz necessário o uso desta ferramenta como apoio para formação superior nos cursos de Administração".

Podemos destacar como principal vantagem do uso desta ferramenta no ensino superior, o fato de trazer para sala de aula um contexto próximo à realidade dos negócios que estes alunos estão se preparando para gerir, para Pessôa e Filho (2001, p.141),

(...) é muito enriquecida a formação do profissional que tem oportunidade de simular no computador o contexto da empresa e do ambiente empresarial, destacar as variáveis relevantes e seu equacionamento, definir estratégias possíveis e receber, quase que imediatamente, os resultados de meses ou anos de projeção futura da evolução dos negócios.... aluno não só se situa na posição de executivo que define pelas suas decisões os rumos de sua empresa, como vê logo em seguida os resultados dessas decisões e sente intimamente os erros e acertos, numa visão sistêmica e dinâmica de todo o seu contexto empresarial e ambiental.

$O$ treinamento com objetivo de formar empreendedores, pelo fato de envolver também uma simulação, oferece um leque de informações aos participantes, dando a oportunidade de conhecerem os diversos setores da organização em um panorama holístico, sem onerar a empresa ou instituição de ensino/treinamento.

Assim, a simulação por meio de treinamentos de empresariais exige do participante dedicação e aplicação de conhecimentos, coragem e ousadia, habilidades necessárias para que eles absorvam o conteúdo abordado. 0 conteúdo abordado pelos treinamentos que utilizam simulações de empresas, ou copia o cotidiano organizacional atraindo a atenção dos participantes que toda via estão buscando conhecimentos práticos. Podemos destacar a competição entre as pessoas, pois estes simulam uma cadeia mercadológica interagindo com: formação de preço, marketing, planejamento e tomada de decisão, exigindo raciocínio lógico e preciso 


\section{Resultados}

Podemos, por meio desta metodologia, afirmar que, dentre as empresas criadas a partir deste trabalho, por ser uma metodologia estruturada e de abertura de empresa de forma consciente, atendendo aos requisitos de gestão de qualidade, que suas empresas geraram mais empregos e renda, sendo que, possivelmente pelo alto índice de conhecimento adquirido, estas empresas são formalmente abertas, o que facilita financiamentos futuros. Destacamos ainda a probabilidade de uma baixa taxa de mortalidade pelo próprio planejamento feito no período pré-abertura da mesma e pelo acompanhamento e encubação das mesmas. Ainda devemos notar a evolução no pensamento empreendedor que o grupo que participará da metodologia obterá, e a geração de emprego, renda e o fortalecimento da economia no médio e longo prazo.

\section{Conclusões}

Em vista do apresentado, e com base no estudo de trabalhos voltados a pesquisar a formação de empreendedores por meio de treinamento empresarial, e ainda o perfil dos egressos destes treinamentos, com base ainda em estudos focados nos resultados de empresários após treinamentos empresariais, acredita-se na hipótese de que pessoas que participam de treinamento de formação de empreendedores têm mais propensão a empreender que pessoas que não participam deste tipo de treinamento.

Até mesmo os de outras formações que não voltada para o empreendedorismo, mesmo, os que não têm tanta iniciativa, ou pró-atividade, mesmo os que não sabem trabalhar em equipe, ou não sabem ouvir, mesmo os que não têm nenhuma ideia brilhante, ou que não se destacaram na escola, ou na faculdade; Mais participaram de treinamentos com objetivo de formar empreendedores realmente após todo o processo educacional, familiarizam-se com conceitos e prática simulada, que tendem a se tornar em diferenciais importantes quando estes buscam oportunidades no mercado, seja como empregadores ou como empregados, passam a empreender de forma sustentável e com boas probabilidades de sucesso.

Ainda por a metodologia sugerida ser um método completo de formação de empreendedores, contendo orientação empresarial, consultorias, financiamento, encubação e formação de arranjo produtivo, com vivência de atividades empresariais, contendo conceitos, regras e critérios organizacionais, como todos os treinamentos empresariais com objetivo de formação de empreendedores encontrados no mercado, o trabalho contribui para uma avaliação favorável, enquanto ferramenta importante para treinamento e desenvolvimento de empreendedores, e aponta no sentido de que poderia ser usado com maior frequência nas políticas públicas visando o desenvolvimento econômico e financeiro regional não só no Brasil como no mundo.

\section{Referências}

MENDES, MARIA DE LOURDES, O Modelo GS-RH: Uma Integração de jogos de empresas para treinamento e desenvolvimento gerencial, Florianópolis, UFSC-SC, Dissertação de Mestrado, 1997.

ORLANDELI, R. Um Jogo de empresas envolvendo cadeia logística: Game F61- Um enfoque educacional. Dissertação de Mestrado em Engenharia de Produção da Universidade Federal de Santa Catarina, 2001.

PESSÔA, MARCELO \& FILHO, PAULO, São Paulo. SP, Jogos de Empresas: Uma metodologia para o ensino de engenharia ou administração, Universidade Paulista-SP-2001.

SANTOS, R. V. dos. "Jogos de empresas" aplicados ao processo de ensino e aprendizagem de Contabilidade. Revista Contabilidade e Finanças - USP, São Paulo, n. 31, p. 78-95, jan./abr. 2003.

AMARAL, Miriam Maia \& VILARINHO, Lúcia Regina Goulart. Surfando na sociedade da informação e do conhecimento: a questão das competências docentes. Boletim Técnico do Senac: a Revista da Educação Profissional. Rio de Janeiro, v 34, n. 1, jan/abr 2007.

BORDONI, Tereza. Habilidades e Competências. A \& E - Atividades e Experiências. Curitiba. Ed. Positivo, $n$ 2, ano 9, maio de 2008. 
CASTRO, Nivaldo José de; ROSENTAL Rubens; ARAÚJO Viviane. Educação a Distância e a construção de competências: desafios na cultura corporativa. Boletim Técnico do Senac: a Revista da Educação Profissional. Rio de Janeiro, v 33, n. 3, set/dez 2007.

GRAMIGNA, Maria Rita Miranda. Jogos de empresa. São Paulo: Makron Books, 1993.

LOPES, Paulo. Reflexões sobre as bases de formação do administrador profissional no ensino de graduação. Anais do XXVI ENANPAD. Salvador, 2002.

NOVICK, Victor. Competências socioambientais: pesquisa, ensino, práxis. Boletim Técnico do Senac: a Revista da Educação Profissional. Rio de Janeiro, v 33, n. 3, set/dez 2007.

STEWART, Thomas A. Capital Intelectual a nova vantagem competitiva da empresa. Rio de Janeiro. Elsevier, 1998.

SAUAIA, Antonio C. A., Jogos de empresas: aprendizagem com satisfação. Revista de Administração, vol.32, n³, p.13-27, jul./set. 1997. São Paulo.

FERREIRA, J. A. Jogos de empresas: modelo para aplicação prática no ensino de custos e administração do capital de giro em pequenas e médias empresas industriais. 2000. Dissertação de Mestrado em Engenharia da Produção - Universidade Federal de Santa Catarina, Florianópolis. 2000.

FAGUNDES, Mário. Modelos de habilidades e competências. Ano de publicação 2000 Disponível em <http://www3.catho.com.br/salario/action//artigos/Modelos_de_Habilidades_e_Competencias> Acessado em 06 de fevereiro de 2008.

Maria H. Araújo e Rochel M. Lago. O Estimulo ao Empreendedorismo nos Cursos de Quimica: Formando Quimicos Empreendedores, Quim. Nova, Vol. 28, Suplemento, S18-S25, 2005.

HOFFMANN, Anders (2007), - "A Rough Guide to Entrepreneurship Policy", in Handbook of Research on Entrepreneurship Policy edited by Roy Thurik, David Audretsch and Isabel Grilo, forthcoming at Edward Elgar Press, 2007. 


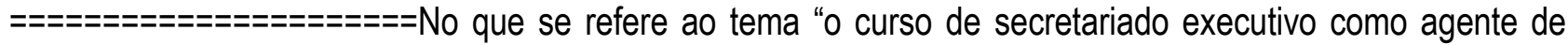
formação de empreendedores", sua escolha se deu em prol deste fazer parte de uma gama de discussões acerca da área de empreendedorismo como atividade liberal para o profissional de secretariado, uma vez que este profissional tem buscado a expansão de suas atuações e a auto-empregabilidade, ao qual remete a um novo perfil profissional que pode ser identificado como "secretário empreendedor".

Hoje um tema muito discutido é o empreendedorismo: a formação de habilidades e competências gerenciais e empreendedoras, mais como os profissionais de secretariado executivo vêem a sua capacidade e a oportunidade de atuar como empreendedores de negócios exercendo a profissão aplicando seus conhecimentos profissionais deixando de ser assessor para atuar como empresário, tornando-se dono de negócios. Frente a isto, buscou-se averiguar como o curso desenvolve ações para o despertar destas pessoas para que possam desenvolver requisitos e características que os levem a empreender e se os egressos do curso de secretariado executivo estão criando empreendimentos e negócios na área após a formação.

Com base nestas informações, a questão que está a merecer urgente atenção é: Será que o curso de secretariado executivo está atuando devidamente como agente formador de profissionais para o mercado de trabalho, sua empregabilidade, atuação ou formação empreendedora? A partir do exposto, indaga-se: Como 0 profissional de secretariado pode ser visto no âmbito da capacidade empreendedora? 0 curso de Secretariado Executivo é agente formador de empreendedores?

Contudo, alguns profissionais encontram uma série de dificuldades, pois muitos acreditam que o melhor é estabilizar-se no setor público, na maioria das vezes, deixando de atuarem como secretários executivos não alcançando uma amplitude, tal qual a sua de dono do negócio enfrentando os desafios do mercado. Diante disso, levanta-se o seguinte questionamento: Quais as possibilidades de atuações do profissional de secretariado como empreendedor de negócios? Com suas competências, habilidades e experiências ao lado de executivos têm capacidade para ser um empreendedor de sucesso aplicando seus conhecimentos secretariais?

Nesse contexto, diante das dificuldades enfrentadas por estes no mercado e os paradigmas da profissão, em virtude de um cenário mercadológico desfavorável em alguns fatores, desde o contexto histórico da profissão os profissionais vem buscando adaptar-se as transformações organizacionais no mercado de trabalho e vem buscando novas alternativas e possibilidades de atuações dentro e fora das organizações.

Posto isso, a área secretarial está conhecendo um novo profissional, o secretário executivo inovador assumindo uma posição de responsabilidade no âmbito de empresário tornando-se dono de negocios e de empreendimentos, tomando decisões, exercendo a liderança e visualizando o campo empreendedorismo como uma área de oportunidades e não apenas necessidade, planejando ações a serem realizadas, controlando, organizando, dirigindo e executando atividades secretariais em seus próprios empreendimentos sem deixar de lado a área secretarial.

O objetivo deste trabalho centraliza-se em analisar se o curso de secretariado executivo está formando profissionais para o mercado de trabalho, sua empregabilidade, atuação ou formação empreendedora. A hipótese que norteou a elaboração da pesquisa é a de que os Bacharéis em Secretariado Executivo estão tornando-se empreendedores de negócios e passando a atuar como executivos face ao desenvolvimento de seu perfil contemporâneo e sua percepção de tornar-se dono de negócios não apenas por necessidade, entretanto, pelas oportunidades desmitificando a idéia de somente atuar como assessor por toda a carreira.

Atualmente, observa-se que para muitos profissionais de secretariado o problema é a falta de investimentos financeiros para a abertura de novos negócios, ou seja, fomentos. Além disto, há diversos fatores de desvalorização dos profissionais de Secretariado Executivo que influenciam na permanência ou ausência destes no mercado de trabalho como: gestores e executivos que desconhecem as atribuições dos profissionais, 
suas competências e habilidades que possuem tal qual para assumir um cargo de gestão ou tornar-se um executivo.

Deste modo percebe-se então que estes profissionais vêm buscando novas possibilidades de atuações como, por exemplo, a de ser um empreendedor de negócios, seja na área secretarial ou em outras áreas de acordo com a melhor opção no mercado. Adiante a este fato é indispensável que o curso de secretariado executivo norteie esta nova possibilidade aos acadêmicos para que possam aprender a trilhar novos caminhos e tenham a alternativa de optar por tornarem-se empreendedores de negócios já que a formação é ampla em variadas disciplinas e conhecimentos ofertados aos profissionais da área. Para fazer consistência a investigação da proposta abordada, problemática, hipóteses e resultados da análise foi realizada uma pesquisa de campo com aplicação de questionários com perguntas pertinentes para obtenção de êxito nas averiguações e propostas desta pesquisa que demonstrou a confirmação da hipótese.

Metodologicamente, o texto está organizado em quatro seções: A primeira vem ser a Introdução, a segunda aborda o "Empreendedorismo". Na terceira "Secretariado Executivo e Novas Frentes de Negócios". A quarta seção corresponde à metodologia e resultados da pesquisa de campo com realização de análise de dados seguido pela conclusão da pesquisa. Nas considerações finais deste trabalho serão apresentadas as conclusões de cada temática especialmente no que se refere a análise de dados. Diante deste prisma 0 propósito deste trabalho é, portanto, contribuir para as discussões acerca do tema empreendedorismo, relacionando-o, ao campo de atuação do profissional de secretariado executivo.

\section{Revisão Teórica}

O empreendedorismo possui seu papel fundamental para o desenvolvimento da sociedade e de um estado. Nesse sentido, é uma área que merece ser tratada com diferencial já que através da área serão geradas autoempregabilidade, satisfação profissional e desenvolvimento de competências e habilidades para profissionais das mais diversas áreas no mundo contemporâneo. Pela sua importância atualmente representa mais para 0 século XXI que revoluções representaram no século passado. Este por sua representatividade passou a ser uma nova vertente aos profissionais de Secretariado Executivo, tornando-se um novo prisma para abrilhantar e engrandecer os conhecimentos e a vida profissional de Secretários Executivos. Contudo, profissionais de Secretariado Executivo vem a partir deste, aperfeiçoando seus perfis empreendedores através da prática de seus conhecimentos com novos negócios buscando expandir sua área de atuação desmistificando o fato de somente atuar como assessor tendo em vista que é qualificado e preparado academicamente para obter capacidade de criar e inovar em várias frentes de negócios na área secretarial.

\section{Empreendedorismo}

Segundo ROBSON TAVARES A, C. (2008) em termo histórico, a palavra empreendedorismo deriva do Frances entrepreneur que traduzido no idioma Inglês da-se origem ao termo intrepreneurship, termo que se interliga a pessoas de negocios, inventores de novas criações. O empreendedorismo com a consolidação da sociedade capitalista passou a ter mais visibilidade e reconhecimento na sociedade tornando-se uma área em foco para pesquisas.

O empreendedorismo ainda é uma ciência moderna desde sua origem, uma novidade que com as mudanças históricas ganhou novos conceitos e definições de ângulos diferentes, entretanto, que falam de um mesmo tema. Uma forma de liberdade para criar e ousadia para inventar que só depende da criatividade das pessoas. Contudo, uma definição atual que aponta a realidade de uma temática contemporânea é a de DORNELAS (2001, p.37) que se baseia nas diversas definições já vistas, "o empreendedor é aquele que detecta uma oportunidade e cria um negócio para capitalizar sobre ela, assumindo riscos calculados" características de uma ação de empreender criando algo novo e diferenciado em meio às oportunidades com dedicação e persistência naquilo que se propõe a fazer para alcançar suas metas e objetivos assumindo riscos calculados. 
$\mathrm{Na}$ busca por novos espaços e oportunidades os profissionais de secretariado aderiram ao empreendedorismo de negócios assumindo riscos em vista de oportunidades. O mercado passou a exigir ao longo das décadas profissionais com perfil empreendedor e intra-empreendedor tornando estes profissionais multifuncionais e cada vez mais polivalentes conforme NATALENSE (1995).

A partir disto os paradigmas relacionados à profissão começam a ser quebrados. Conceitos antigos, creditados erroneamente por indivíduos sem visão abrangente do contexto do mundo dos negócios, são revistos e substituídos. O secretariado executivo passa a ser fundamental nas organizações, junto aos executivos, na busca pelo lucro e no mercado competitivo inclusive aprendendo novas habilidades gerencias e competências para o empreendedorismo.

Nesse novo contexto, que continua com notórias evoluções até os dias atuais, GARCIA E D'ELIA (2005) sintetizam a evolução do perfil do profissional, focando-se no início da década de 1970 até os dias atuais: Enfim, o perfil do secretário do terceiro milênio deve reportar-se a um profissional com postura ética, empreendedora e negociadora. Ele é capaz de trabalhar em equipe e ser um agente de mudanças (AZEVEDO; COSTA, 2006). É alguém que desempenha papéis polivalentes, lidera grupos e mantém uma boa comunicação, bem como administra conflitos e relacionamentos entre clientes internos e externos.

Dessa forma, compete ao profissional secretarial a iniciativa de se adaptar ao novo perfil e aos futuros, pois diante de inúmeras mudanças dentro das organizações e no mercado de trabalho em um curto período de tempo, esse novo perfil secretarial se tornará obsoleto (AZEVEDO; COSTA, 2006). Tendo em vista que é necessário um diferencial para o futuro, a formação empreendedora que por sua vez vem ser uma otimização de preparo para secretários executivos. O profissional de secretariado pode ser um empreendedor empresarial, buscando um novo caminho para sua vida profissional na prática de seus conhecimentos acadêmicos adquiridos na universidade.

O empreendedorismo é uma nova competência para o novo perfil profissional de secretariado executivo que esta no mercado. As características empreendedoras aparecem no cotidiano destes profissionais. Os cursos de secretariado executivo exercem grandes influencias nas decisões dos mesmos em função da abrangência das disciplinas e dos conteúdos ministrados pelas universidades.

As instituições de ensino precisam preparar os acadêmicos para o mundo dos negócios. O sucesso é decorrente de diversos fatores e entre eles o perfil profissional destaca-se como ponto chave para obtenção do sucesso de qualquer profissional, dentre eles destaca-se o profissional de Secretariado Executivo. Segundo BARROS (2014, p.2,) "para que o sucesso aconteça, é necessária uma dose de visão de futuro, autonomia, organização, capacidade de estabelecer metas, autoconfiança, planejamento de carreira, network entre outras." 0 profissional tem um perfil que se adéqua ao empreendedor por suas características singulares o que pode ser aperfeiçoado cada vez mais através de aprendizados e práticas empreendedoras e aprendizados contínuos.

Ser Secretária Empreendedora é ter prazer no trabalho mudando e transformando com toda energia e vontade tudo e todo trabalho ao seu redor, planejando e realizando com independência e auto-confiança suas atividades, correndo e assumindo os riscos, resistindo aos obstáculos e construindo pontes favoráveis, alinhando os objetivos com a missão maior da empresa. Os profissionais de Secretariado têm ma característica importantíssima; a intuição, capacidade esta que leva a melhor dimensionar os fatos, concretizar metas, aceitar os erros, recomeçar se necessário, aprender e reaprender, criar, solucionar problemas, confiar, flexibilizar e interagir. São profissionais que possuem o perfil que mercado busca e almeja.

Diante do contexto é imprescindível que os profissionais de Secretariado Executivo percebam novas frentes de negócios já que são profissionais estudam nas universidades empreendedorismo e gestão de negócios, atribuindo-lhes capacidade de gestão e empreendedor. Nesse contexto, suas experiências e sua qualificação Ihe permitem tornarem-se donos de negócios na área secretarial, porém observa-se que há diversos profissionais que empreendem em outras áreas tendo em vista que é importante propiciar aos mesmos que é possível empreender negócios na área a pesar de ser uma área voltada para o assessoramento executivo.

\section{Novas frentes de negócios}


Os tipos de negócios para os profissionais de secretariado executivo na área podem ser criativos e iniciados através de dois pontos chaves: pessoas e espaços. Assim, primeiramente, usar a criatividade e perceber o que se têm para criar, pois trabalhar com pessoas pode-se obter colaboração, interação, uma agenda de relacionamentos e ideias, através de espaço é possível obter criatividade, ferramentas, possibilidades, suportes, facilidades e coletividades.

Diante destes pontos chaves é importante enfatizar que a gama de conhecimentos dos profissionais da área permite que este profissional possa vir a trabalhar liberalmente como consultor em diversos tipos de atividades lidando com pessoas e organizações. Através de seu espaço empresarial organizaria, coordenaria e planejaria eventos e cerimoniais além de uma possível atuação como palestrante, prestando ainda serviços de diversas atividades secretariais, podendo também elaborar projetos e realizaria suas atividades enquanto profissional da área.

Uma nova opção de mercado para o profissional de secretariado seria um espaço virtual para mostrar serviços e prestação de serviços, assessoramento. Negócios com escritórios virtuais e consultorias. Com escritórios virtuais é possível uma troca de conhecimentos, prestações de diversos serviços com fornecimento de suporte para alcance de objetivos fins além de ser uma ótima forma de se aliar tecnologia e internet favorecendo as habilidades dos profissionais de secretariado com novas tecnologias. Dessa forma criaria então escritórios virtuais. Segundo DANUSA DIAS e CAMILA CUNHA (2014, p.35):

0 profissional de secretariado precisa ter consciência de que sua atuação no mercado vai muito além da área da assessoria, ele é multifuncional e atua em uma área que possui muitas frentes de trabalho. Assim unindo seus conhecimentos obtidos na academia, acrescidos de experiência prática, e seu perfil empreendedor perspicaz entende-se que este pode sim ser o líder, e trabalhar por conta própria, pois este possui base, conhecimento, experiência prática, habilidades técnicas e outras tantas características que o permitem ter papel de gestor, com isso pode optar por trabalhar em outras áreas, como a consultoria, por exemplo, uma vez que este profissional possui amplos conhecimentos específicos na área de gestão, assessoria, consultoria e empreendedorismo.

O mercado de trabalho vem caracterizando-se por sua instabilidade e competitividade, dessa forma se torna cada vez mais importante que os profissionais busquem novas alternativas que possibilitem aumentar sua empregabilidade. Os profissionais de secretariado executivo hoje deixaram para trás aquele perfil caricato de servir café para exercer um perfil empreendedor com papel fundamental no mercado.

Uma das possibilidades de atuar como profissional autônomo é tornar-se um consultor, tendo em vista que pode consultorar em diversas áreas relacionadas há área de secretariado. Diante do contexto é importante se ter uma noção conceitual de consultoria. De uma forma abrangente consultoria vem ser uma prestação de serviço, ou fornecimento de determinada atividade por profissionais qualificados, especializados, experientes e conhecedores do tema ou serviço.

PORTELA (2009, p. 29), afirma da seguinte forma: "Os consultores, igualmente ao profissional de Secretariado Executivo, possuem todas essas características que os tornam capacitados a exercerem a consultoria".

Para o profissional de secretariado executivo é importante frisar que com a riqueza de conhecimentos adquiridos na graduação e a portabilidade para se especializar em diversas áreas é possível realizar consultoria em diversos segmentos como Consultoria em assessoria executiva atendendo executivos na realização de encontros de negócios e eventos, como seminários e palestras. Recepcionar clientes brasileiros e estrangeiros em visitas, congressos e convenções. Assessorando executivos em viagens nacionais e internacionais prestando serviços secretariais.

Consultoria em tradução e versão de idiomas, escrever textos em idiomas estrangeiros e traduzir documentos para o português. Fazer a tradução simultânea em reuniões, debates e seminários. Consultoria em organização de eventos locais, regionais, nacionais, internacionais, individuais ou coletivos realizando planejamentos e 
organizações de atividades como: roteiros de solenidades, orçamentos, provendo oradores, organizando decoração, mesas, tendas, prestando suporte e apoio ao evento e outros. Dessa forma buscaria novos formatos e experimentos na área de eventos.

Consultoria em gestão empresarial, trazendo através de um diagnóstico financeiro, avaliação dos processos operacionais e de gestão, permitindo identificar os pontos críticos e indicando as ações de melhorias necessárias, com conseqüências diretas nos resultados financeiros, qualquer que seja o porte e o ramo de atuação da empresa. Ajudando a empresa a melhorar a sua operação e gestão para obter os melhores resultados. Para DANUSA DIAS e CAMILA CUNHA (2014, p.32) "Uma boa consultoria leva em consideração as reais condições da empresa e do mercado e da conjuntura geral para atuar de forma a atingir os resultados esperados."

Um consultor de negócios influencia nas decisões de seus clientes, pois este aconselha, traz soluções, idéias e soluções além de estratégias. Ainda de acordo com as autoras esta atividade é possível aos profissionais de secretariado em vista destes terem visão generalista, com técnicas intelectuais, racionais, sociais e políticas de liderança. Como consultor recomenda, adverte, orienta e direciona as pessoas a enxergar o problema de uma forma mais clara e realista. Isto também se deve as experiências ao lado de executivos de alto escalão em empresas de grande porte, pois é um profissional que sabe lidar com situações novas e mercado.

Outra opção para estes seria a consultoria de negócios realizando encontro de negócios aproximando empresas que prestem serviços na área de secretariado executivo com organizações que precisam de profissionais qualificados na área, bem como em outros ramos além de proporcionar orientações sobre serviços, atividades na área secretarial e administrativa. Configurando-se em aconselhamento a executivos referente a todos os temas de negócios e pessoas aproximando as organizações e pessoas há área secretarial fazendo com que estes conheçam as atribuições e qualidades de um profissional de secretariado executivo.

Além destas, é preciso mencionar "coaching" treinamento em secretariado para desenvolver pessoas e talentos nas organizações ou através de seu próprio negócio apoiando, encorajando, motivando e acompanhando ações que melhorem o profissionalismo e a vida pessoal atingindo transformações positivas de acordo com o desejo dos clientes.

O profissional de secretariado executivo é um profissional preparado para propor soluções e respostas aos problemas, dificuldades e desafios, oferecendo também bons processos e novas criatividades como propostas para gestões e organizações que enfrentam no cotidiano as mudanças mercadológicas, gerando resultados, assim é importante destacar a capacidade deste de elaborar projetos, bem como mais uma oportunidade de atuar liberalmente.

Com consultoria é possível atuar como autônomo e na área de secretariado, pois desta forma os profissionais não precisariam deixar a área e a profissão fora de contexto profissional criando negócios em outros ramos. Pois mesmo que seja necessário analisar mercado e demandas para abertura de negócios, também é possível a criação de negócios na área, oportunizando até mesmo outros profissionais da área a atuarem profissionalmente em empresas de secretariado e consultoria prestando serviços.

Além de escritórios virtuais profissionais de secretariado poderiam ter escritório com vários profissionais associados para prestações de serviços a terceiros, ou trabalharem com terceirização de serviços administrativos e assessoria. Nesse contexto, os profissionais teriam mais tempo e qualidade de vida, com boas remunerações, em resumo a atuação liberal traz estes benefícios, gerando ainda satisfação e motivação profissional, pois profissionais qualificados querem estar no mercado de trabalho. Se o no mercado houverem fatores que influenciem na sua permanência ou ausência como empregado, estes podem criar e experimentar novas oportunidades de negócios na área.

De acordo com DURANTE E BARBOSA (2013, p.17) através de um estudo observaram que o empreendedorismo é uma nova realidade para os profissionais de secretariado executivo onde segundo as autoras.

As características empreendedoras e intra-empreendedoras são potencializadas pela formação do Secretário Executivo que, por ser ampla e agregar conhecimento de várias 
áreas, dá embasamento e motivação para o profissional firmar-se como empresário de sucesso. Dessa forma, o exposto permite elucidar que o empreendedorismo é uma realidade na profissão secretarial.

Haja vista que tais novas opções de trabalho e atuação profissional sejam novos prismas de evolução na profissão secretarial, vale a pena apontar o empreender, o inovar, o criar um empreendimento, ou abordar a prática de inovar no mercado de trabalho através do empreendedorismo, não deixando de ser um profissional da área secretarial para tornar-se apenas um gestor de negócios, más ser um profissional de secretariado criando novas possibilidades de carreiras com capacidades além da gestão tornando-se gestor e empreendedor.

De acordo com DORNELAS (2001, p.10):

Todo empreendedor necessariamente deve ser um bom administrador para obter o sucesso, no entanto, nem todo bom administrador é um empreendedor. 0 empreendedor tem algo mais, algumas características e atitudes que o diferenciam do administrador tradicional.

$O$ autor destaca que nem todo empreendedor pode ser um bom gestor que venha obter sucesso. Diante do contexto, é importante frisar que os profissionais da área secretarial além da capacidade de gestão podem ser excelentes administradores de negócios e empreendedores dependendo da formação acadêmica e da sua vontade própria de buscar qualificar-se e de aprimorar seus conhecimentos para empreender.

A grandeza dos conhecimentos e a capacidade de criatividade dos profissionais de secretariado executivo são muito mais que apenas uma simples capacidade de gerir um negócio, secretariar ou assessorar. 0 que se tem observado no momento é que falta-lhes percepção de campos de atuações para novas possibilidades empreendedoras na área de secretariado executivo o que faz com que estes tornem-se empreendedores, porém em outras áreas, tornando-se assim empreendedor de negócios, más não na área de secretariado.

Resumidamente, compreende-se que falta um despertar de acadêmicos e egressos para possibilidades de atuações e negócios para o profissional de secretariado. Quanto mais oportunidades de negócios na área, maiores as chances da ascensão da profissão e vantagens de novas frentes de negócios para os profissionais de secretariado executivo.

\section{Procedimentos Metodológicos}

Quanto ao tipo de pesquisa e sua natureza esta se refere a um estudo exploratório e descritivo. A pesquisa exploratória ocorre de maneira que se permita o amplo e detalhado conhecimento do objeto estudado com finalidade descritiva para construção de hipóteses. Sendo a presente pesquisa descritiva os dados tendem a ser analisados individualmente.

Segundo GIL (2008) com uma pesquisa exploratória é possível familiarizar-se mais com o assunto estudado, para o autor quase sempre este tipo de pesquisa assume a forma de um estudo de caso. No que se refere aos objetivos está é uma pesquisa exploratória, sendo que como o próprio nome indica, a pesquisa exploratória permite uma maior familiaridade entre o pesquisador e o tema pesquisado, visto que este ainda é pouco conhecido, pouco explorado. Porém, de acordo com GIL (1996, p.78):

Por ser uma pesquisa bastante específica, pode-se afirmar que ela assume a forma de um estudo de caso, sempre em consonância com outras fontes que darão base ao assunto abordado, como é o caso da pesquisa bibliográfica e das entrevistas com pessoas que tiveram experiências práticas com o problema pesquisado.

No que condizem aos procedimentos, esta se conduziu em uma pesquisa bibliográfica, ou seja, pesquisa exploratória, uma vez que em primeiro momento houve um estudo realizado a partir de material já publicado, constituído principalmente de livros, artigos de periódicos e atualmente com material disponibilizado na Internet no que condiz inicialmente com referencial teórico para estudo. 
Em vista do apresentado, no que se refere a esta ser descritiva, tratou-se da descrição e caracterização dos dados dos entrevistados, com forma de aplicação de questionários. De acordo com OTANI e FIALHO (2011, p.36) explicam que este tipo de pesquisa "envolve a utilização de técnicas padronizadas, coleta de dados, questionário e observação sistemática. Em geral assume a forma de levantamento", em vista dessa referencia compreende-se que este tipo de pesquisa aprofunda o conhecimento da realidade além das aparências do que é apresentado explicando o porquê das coisas e ocorrência de fenômenos. Em relação ao critério de escolha e caracterização do banco de dados esta pesquisa é qualitativa e quantitativa.

Assim, como forma de comprovar as hipóteses levantadas foi realizada uma pesquisa de campo consistindo em investigações empíricas, com análises de fatos, na qual é uma forma de quantificar o tema abordado. Para atingir o objetivo proposto com base no referido assunto realizou-se uma pesquisa de campo subsidiada por questionários, com a função primordial de constatar os dados coletados na pesquisa bibliográfica, e ainda com o objetivo central de entender melhor o conceito sobre o curso de secretário executivo como agente formador de empregabilidade e empreendedorismo. Deste modo aliando a pesquisa bibliográfica com pesquisa de campo gerando teoria e prática.

Dessa forma, foram analisados os dados coletados conforme as principais temáticas abordadas no trabalho. 0 critério utilizado para a coleta de dados ocorreu da seguinte forma: primeiramente definiu-se o público alvo: egressos do curso de secretariado executivo. Solicitou-se junto à coordenação do curso de Secretariado Executivo da Universidade Federal do Amapá - Unifap uma relação cadastral de alunos concluintes do curso, entre os anos de 2000 a 2014. Os questionários foram aplicados para uma população com número de 168 pessoas, o que correspondeu a uma amostra com um total de 87 questionários respondidos pelos entrevistados, sendo que, 140 entrevistas foram realizadas através de e-mails, 18 questionários foram preenchidos através de contato pessoal, e apenas 10 , foram obtidos por contato telefônico. Considerando que o levantamento foi realizado no período entre 28 de novembro a 20 de dezembro de 2014.

Quanto ao gênero sexual observou-se que o sexo feminino é predominante na profissão de secretariado executivo, 60 dos entrevistados foram mulheres e 27 homens apenas, completando as 87 entrevistas respondidas com êxito. Com intuito de realizar entrevistas pessoais com egressos, foi elaborado no programa Word, o modelo de questionário fechado contendo 13 perguntas com espaços para comentários opcionais correlacionados ao tema para fins de investigações, comprovações ou refutações de hipóteses. Foi elaborado no sistema Google Drive o mesmo modelo de questionário para enviar via e-mail aos entrevistados.

Todos os dados obtidos na coleta de dados foram incluídos no sistema on-line, em um programa no Google Drive, onde neste foi criado o questionário que foi enviado há e-mails para coleta de dados que facilitou a visualização das respostas, oferecendo gráficos e totais de respostas obtidas com dados coletados que correspondeu a pesquisa de campo onde serão apresentados a seguir por meio de gráficos e tabelas tabulados no Excel para geração de percentual de dados.

A finalidade do estudo consistiu-se em descobrir se o curso de bacharelado em secretariado executivo da Universidade Federal do Amapá está realmente formando profissionais com competências e habilidades, e despertando os acadêmicos da área para o empreendedorismo como uma nova possibilidade de atuação no mercado de trabalho já que é um agente na formação acadêmica. Contudo, tratando-se em descrever se 0 curso de secretariado executivo está formando profissionais para o mercado de trabalho, sua empregabilidade, atuação ou formação empreendedora.

\section{Pesquisa de campo e resultados}

Os resultados da pesquisa buscaram evidenciar as hipóteses presentes no referencial teórico, para tanto os dados mostraram inicialmente que apenas $74 \%$ dos profissionais de secretariado executivo estão trabalhando onde uma parte em sua grande maioria estão no setor público, uma pequena parte no setor privado e outro pequeno percentual é empreendedor de negócios. Neste contexto, observou-se também que $26 \%$ dos entrevistados estão desempregados e sem trabalho autônomo. 


\section{Situação de empregabilidade dos profissionais de secretariado executivo no Amapá e novas possibilidades de atuações}

Observou-se que do percentual de $74 \%$ dos que estão trabalhando um percentual de $16 \%$ de profissionais formados em secretariado executivo atuam como secretários empreendedores e gestores. Tornaram-se "donos de seus próprios negócios" decidindo uma nova vertente de atuação profissional como empreendedores na qual correspondem estes dados. Este percentual reforça a tendência dos profissionais buscarem a expansão de suas atuações, o que já vem ser uma realidade desde os primórdios do surgimento da profissão por ser uma carreira que vem enfrentando os desafios do mercado de trabalho.

Contudo, nenhum dos entrevistados declarou-se ser empreendedor de negócios na área de secretariado. $\mathrm{A}$ pesquisa deixou evidente que $16 \%$ dos entrevistados tornaram-se empreendedores em outras áreas criando seus negócios em outros ramos em vista do que o mercado Amapaense oferece como oportunidade.

Uma outra realidade evidenciada pela pesquisa realizada e o que os secretários executivos entrevistados relataram quanto ao mercado de trabalho local, no estado do Amapá, é que o estado ainda necessita de maiores desenvolvimentos para abrir novas possibilidades empregatícias e oportunidades de carreira, sendo que parte das empresas locais não possuem estrutura para absorver profissionais bem capacitados e preparados para ingressar no mercado de trabalho.

Profissionais apontaram o fato de o Estado não ter empresas de grande porte para agregar os profissionais de secretariado executivo, uma vez que o curso é voltado para o mercado de trabalho. Por este motivo os profissionais tendem a buscar novos caminhos profissionais, entre eles o empreendedorismo. Além destes fatos a pesquisa demonstrou que parte dos entrevistados exerceu a função de secretariado executivo, entretanto, no reconhecimento em carteira profissional poucos obtiveram registro na Carteira de Trabalho Profissional com título de secretário executivo. Neste contexto, muitos tiveram títulos como assistentes ou auxiliares administrativos apenas, em sua maioria.

Isto reforça a falta de reconhecimento por parte das organizações do estado em reconhecer as competências e habilidades que estes profissionais adquirem na academia além de não realizarem os devidos registros para não pagarem o piso salarial ao qual faz jus a categoria como demonstraram os dados em que $45 \%$ dos entrevistados afirmaram ter exercido atuação na área especificadamente apenas quando ainda estudavam e eram estagiários, enquanto apenas $55 \%$ já exerceram a função específica com reconhecimento.

Um outro fato relevante a abordar nesta análise é que parte dos profissionais que estão no setor público, não atuam na área de secretariado executivo, haja vista que ainda há poucos concursos públicos na área e quando há são poucas vagas para o cargo. Além deste fato uma observação a respeito deste fato é que muitos cargos de secretariado dentro do estado são ocupados por pessoas não qualificadas e sem a formação acadêmica, 0 que dificulta a ascensão da profissão dentro do Estado.

Ainda com a análise de dados objetivou-se investigar que concepção os profissionais de secretariado executivo tinham a respeito do empreendedorismo como uma nova alternativa de empregabilidade e atuação no mercado. Deste modo levantou-se o seguinte questionamento: Se ser empreendedor de negócios seria uma alternativa de empregabilidade para os secretários executivos? Onde foi extremamente relevante para saber se os profissionais tinham visão de que o empreender é uma portabilidade de manter-se empregado e atuar no mercado como mostra a analise a seguir.

O empreendedorismo de negócios como uma alternativa de empregabilidade para os profissionais de Secretariado Executivo.

Foi satisfatório o resultado deste questionamento resultando em um percentual de $98 \%$ de entrevistados, onde 
se constatou que estes compreendem e sabem que o empreendedorismo faz parte do perfil de um profissional de secretariado executivo. Constatou-se ainda que muitos profissionais almejam tornar-se empreendedores de negócios enquanto não aparecem boas oportunidades no mercado Amapaense.

Em relação ao perfil de um profissional de secretariado executivo empreendedor, os entrevistados afirmaram que "o secretario executivo é um gestor e empreendedor nato, são profissionais versáteis e ágeis, o que é impressionante para o perfil empreendedor". De acordo com os entrevistados: o empreendedorismo faz parte das habilidades dos secretários executivos, pois o profissional enquanto acadêmico estuda para ter visão holística, ou seja, visão futurística e teoricamente é preparado academicamente para desenvolver habilidades empreendedoras ainda na universidade.

Segundo os profissionais entrevistados, os profissionais podem ser criativos, inovadores, cheio de ideias que podem ajudar no crescimento dos negócios, entretanto, apontaram para um despertar da universidade em criar uma disciplina que possibilitasse a prática do empreender dentro da universidade, como por exemplo um laboratório, além da empresa Junior, mais prática nesta, aliada a teoria. Para os entrevistados inovação é a palavra-chave, para eles o secretario executivo tem sempre novas visões do futuro.

A pesquisa evidência que mesmo que se considere que a maior parte dos secretários executivos entrevistados admitam que o empreendedorismo faça parte do perfil profissional de um secretario executivo e que considerem que o empreendedorismo seja uma ancora para a empregabilidade trazendo a possibilidade de atuar como gestor e empreendedor de negócios aplicando seus conhecimentos, ainda assim são poucos secretários que empreendem em algum negócio no estado correspondendo a um percentual de apenas 16\% como mostra 0 gráfico a seguir.

\section{Profissionais de secretariado executivo que são empreendedores e gestores de seus próprios empreendimentos}

Observou-se que os negócios e empreendimentos não são na área secretarial, entretanto, os gestores são profissionais de secretariado executivo e que afirmam ter interesse em abrir novos negócios na área da profissão. Por outro lado enfatizam ter visão de mercado e perceber o melhor ramo para investir em negócios já que o importante é que são empreendedores e gestores de seus próprios empreendimentos conquistando salários ótimos além de poder ter reconhecimento como empreendedores de sucesso no estado já que há mercado para tal.

Diante do percentual de $84 \%$ de profissionais que nunca empreenderam em algum negócio ou não empreendem em nada pôde ficar evidente 0 fato de que ainda é necessário levar em conta que alguns profissionais ainda acham que ser secretario executivo é apenas ser assessor deixando de levar em consideração que o profissional da área tem diversas possibilidades de atuações entre elas a de empreender negócios, até mesmo na área secretarial. Entretanto, observou-se que $52 \%$ destes já estão pensando entrar para a estatística de secretários empreendedores no estado tornando-se dono de seus próprios empreendimentos como mostram os dados.

Este fato comprova a tese de que os profissionais de secretariado estão trilhando novos caminhos profissionais voltados ao empreendedorismo de negócios, comprovando a importância do despertar o empreender dentro do curso uma vez que é a chance de agregar esta nova realidade como alternativa de valorização da profissão frente a situação real que a universidade e o estado precisam encarar como solução a tantos embates e desmotivações que a categoria vem sofrendo.

Nesta mesma realidade ficou constatado que parte dos entrevistados pretendem tornar-se empreendedores de negócios, mudando sua visão a respeito de atuações profissionais pretendendo dar um salto na vida profissional ou sair do desemprego. De acordo com os argumentos dos egressos é que há mercado no estado, entretanto, não há valorização da classe, onde os mesmos estão pretendendo buscar a expansão de suas atuações abrindo caminhos para novas atuações e possibilidades empregatícias. Desta forma os mesmos buscam uma nova forma de alavancar e valorizar a profissão em questão onde como empregados não conseguem obter este êxito. 


\section{Profissionais de secretariado executivo que pretendem ser empreendedores e gestores de seus próprios empreendimentos}

Com a análise é possível constatar que do percentual de $52 \%$ que pretendem empreender parte estão desempregados e parte já estão trabalhando na área privada e setor público. Do percentual de $48 \%$ que não tem nenhum interesse em empreender em nenhum negócio em sua grande maioria já tem uma estabilidade econômica pessoal, uma vez que são funcionários públicos. Partindo deste ponto é viável compreender a variável de que o empreendedorismo é uma alternativa de empregabilidade e de geração de renda.

Apesar deste imparcial resultado $100 \%$ dos entrevistados concordaram que o profissional de secretariado executivo pode sim ser gestor e empreendedor de negócios. O que importa para o empreender como um novo destaque e ascensão na profissão de secretariado executivo. No que remete a atuação desses profissionais nos dias de hoje verificou-se que estão buscando expandir suas áreas de atuações. Segundo os entrevistados:

Para os profissionais é preciso buscar novos caminhos em vista das dificuldades para nós enquanto profissionais da área aqui no estado do Amapá, a falta de conhecimento da sociedade sobre a profissão de secretariado estigmatiza o secretario a atender telefone e servir café

Os profissionais de secretariado compreendem que mesmo que no estado haja dificuldades e paradigmas a serem superados, nacionalmente a profissão é bem vista pela sociedade e no meio empresarial. Alguns entrevistados apontaram um fato interessantíssimo de que o profissional de secretariado executivo é mais para a atividade de gestão que a simples assistência executiva, por isso vem buscando atuar na área do empreendedorismo. Outro motivo que impulsiona os mesmos a buscarem a expandir suas áreas de atuações é a competitividade e as mudanças constantes no mercado de trabalho.

Diante dos fatores apresentados concluiu-se que muitos profissionais da área querem estabilidade financeira e profissional por isso buscam o empreendedorismo. De acordo com as entrevistas "os profissionais precisam ter mais estabilidade profissional e no empreendedorismo há oportunidade de se estabilizar financeiramente e profissionalmente". O Amapá tem demandas e oferece um mercado com oportunidades para empreender, pois os entrevistados confirmaram que os profissionais possuem as habilidades para isto e o curso os prepara para tal atividade.

Na pesquisa buscou-se averiguar se o curso bacharelado em secretariado executivo formou profissionais com competências e habilidades que garantam ou norteiem os concluintes a ingressar no mercado de trabalho e de que forma estas poderiam ser melhoradas para garantir empregabilidade aos profissionais.

\section{Desenvolvimento de competências e habilidades na graduação para geração de empregabilidade.}

Observou-se que o percentual de entrevistados que acreditam que precisa ter desenvolvimento de maiores competências e habilidades dentro do curso é um média $94 \%$ um total considerável para reflexão. Para os que disseram sim, para que essas habilidades e competências sejam melhores desenvolvidas é preciso que o curso venha se desenvolver e expandir-se dentro da própria universidade pela sua importância ajudando a profissão a crescer mais no estado.

Dentro deste contexto, de acordo com os dados da pesquisa as amostras revelam que teoria é fundamental e que a prática é essencial para o desenvolvimento dessas habilidades e competências, quanto mais capacitação dentro do curso melhor para que esse desenvolvimento. Atualmente o curso vem buscando isto, um exemplo evidente é a Empresa Júnior, que não deixa de ser uma prática laboratorial. Entretanto, dos $6 \%$ que estão satisfeitos com o resultado que obtiveram durante a graduação, em relação as competências e habilidades, em sua maioria acreditam que depende apenas de cada profissional para esse desenvolvimento da seguinte forma: com capacitação, cursos de aperfeiçoamento, participação em seminários, fóruns e outros. Dessa forma observou-se que estes não levaram em consideração o fundamental papel da universidade, ou desconhecem este fato, pois a formação e o papel de geração de empregabilidade da universidade não termina com a colação 
de grau. Já que a universidade é responsável por formar profissionais e preocupar-se com a situação destes no mercado.

Deste ponto é compreensível que Isto ajudaria no reconhecimento da profissão, ma divulgação do perfil dos profissionais de secretariado executivo no estado, já que o curso é voltado para a empregabilidade e possui um ótimo componente curricular por que não torná-lo mais completo instigando e integrando ao currículo do curso disciplinas especificas que levam ao caminho do empreendedorismo, pois é válido salientar que isto pode mudar o rumo profissional de um secretário executivo.

Uma alternativa abordada para o desenvolvimento das habilidades e competências durante a graduação é o treinamento especializado através de empresas de prestação de serviços de assessoria e empreendedorismo ou treinamento por meio de professores que ofertem disciplinas especificas de empreendedorismo com aulas práticas. Esta é uma sugestão de egressos. Para uma análise verificou-se a concepção e o ponto de vista dos egressos do curso de secretariado para verificar a opinião a respeito do curso, para saber se 0 curso realmente prepara os formandos para ingressar no mercado de trabalho e enfrentar seus desafios

\section{0 curso de secretariado executivo como agente formador e preparatório para ingresso no mercado de trabalho.}

O resultado demonstra que $70 \%$, bem como a maioria dos entrevistados que o curso é uma excelente graduação, com ótimas disciplinas e currículo acadêmico. De acordo com as respostas os estágios nas organizações são a causa e principal razão de complemento para formar profissionais experientes e capacitados. Outra razão é o currículo do curso com sua diversidade de disciplinas teóricas e por ser bastante completo, isto explica o por que de preparar os formandos para ingressar no mercado de trabalho. Nas respostas os egressos explicaram que o curso de secretariado executivo é voltado para o mercado de trabalho, é um excelente curso de graduação, com ótimas disciplinas e currículo acadêmico.

$30 \%$ dos egressos afirmam que o curso precisa melhorar revendo algumas disciplinas que fazem parte da grade do curso, trazendo mais prática dentro da universidade aliando a teorias, necessitando ser mais exigente, dinâmico e específicos em determinadas disciplinas, enfatizando no idioma como um ponto chave para inclusão no mercado de trabalho. De acordo com a opinião destes o curso precisa desenvolver-se, ainda é necessário alguns avanços no curso, entre eles os poucos professores que fazem parte do curso, a falta de um laboratório específico para que disciplinas e assuntos acadêmicos não sejam vistos de forma acelerada impactando no desenvolvimento acadêmico.

Mesmo com todas as dificuldades e obstáculos que o curso vem ultrapassando dentro da universidade para desenvolver-se e trazer com esse desenvolvimento melhorias na graduação e no desenvolvimento de melhores habilidades e competências conclui-se nesta análise que o curso forma profissionais competentes e preparados para ingressar no mercado de trabalho enfrentando desafios, apenas o que os dados evidenciam diante disto é que o curso precisa abrir e mostrar novos caminhos empreendedoriais para não deixar que os profissionais formem-se sem norteio de oportunidades, formando profissionais com visão empreendedora.

Os entrevistados reconhecem que é preciso muito curso de aperfeiçoamento, entretanto o curso em si já deveria abrir caminhos para a empregabilidade dos egressos, compromisso da universidade com, qualidade no ensino, apoio, prática, teoria, pós-formação e incentivo. Estes são fatores que reforçam um passo a frente dos demais no mercado por ter obtido uma formação com diferencial.

Para fins de verificar o que a universidade tem feito para apoiar, incentivar, ou responsabilizar-se de alguma forma pelo ingresso de profissionais formados no mercado de trabalho buscou-se na pesquisa de campo perguntar aos entrevistados.

Formação Acadêmica e Responsabilidade da Universidade para com Ingresso de Profissionais de Secretariado Executivo no mercado de trabalho. 
Diante das informações coletadas com a pesquisa percebeu-se que os egressos não tiveram apoio da universidade, incentivos ou contato de alguma forma com a instituição. $84 \%$ dos egressos afirmaram que sempre tiveram que agir de forma independente, e buscar oportunidades sozinhos sem norteio ou colaboração da Unifap e do curso de secretariado executivo. Neste sentido, os acadêmicos informaram que sempre procuram buscar oportunidades empregatícias antes mesmo de formar por receio de sair da universidade e ficar desempregado. Não intermediação da instituição para ingresso no mercado pós formação ou intenção de projetar ações para ajudar a divulgar e desenvolver o profissional e o curso para o mercado local até mesmo abrindo caminhos para os mesmos.

É importante salientar a dificuldade até para encontrar os egressos, haja vista que na coordenação do curso não há um cadastro em banco de dados com fácil visualização, o que dificulta até o contato com os egressos e a instituição. $O$ que seria de fundamental importância para acompanhar os profissionais no mercado e reter informações essenciais para o desenvolvimento do curso.

Neste sentido, também é compreensível e importante frisar que o profissional formado não pode se isentar da responsabilidade em zelar pelo seu compromisso profissional, suas atualizações constantes e interesse para a excelência no exercício da profissão. Este é um fator que $92 \%$ dos entrevistados reconhecem, pois somente diploma de graduação e formação acadêmica não garantem empregabilidade. Os profissionais também precisam atender as expectativas do mercado para que este continue sendo um ponto favorável aos profissionais no mercado e para o desenvolvimento e crescimento do curso, na qual é a realidade atual.

Na possibilidade de averiguar o mercado e as possibilidades empregatícias para o profissional de secretariado executivo foi perguntado aos mesmo, que por sua vez profissionais bem capacitados no mercado se as expectativas de empregabilidade no estado do Amapá eram boas.

\section{As perspectivas de empregabilidade para o profissional de secretariado executivo no estado do Amapá.}

É perceptível que mais da metade dos entrevistados responderam que sim, dentro desta análise sendo uma das mais importantes deste trabalho é válido reforçar que o profissional de secretariado executivo é de grande importância para uma organização. Visto que sua mutifuncionalidade, sua visão e seus conhecimentos trazem benefícios as empresas, principalmente por serem versáteis e ágeis em relação às mudanças como um todo. Os dados confirmam que $47 \%$ dos profissionais que responderam sim confirmando que há mercado no estado já ingressaram no mercado de trabalho, entretanto, afirmam que ao mesmo tempo em que o estado oferece boas demandas de trabalho poucas empresas querem pagar bons salários a profissionais competentes e com formação superior mesmo que de qualidade.

Sobre o assunto Marcelo Castro (Bel. em Secretariado) argumenta: "O mercado não possui estrutura para agregar novos profissionais formados sendo que são poucas as demandas em empresas que pagam bons salários a pesar de ter mercado para os profissionais no estado do Amapá." Fica evidente que a sociedade Amapaense pouco conhece sobre a capacidade e a necessidade de se obter um profissional de secretariado em uma organização devido sua importância profissional e sua capacitação.

A pesquisa deixa evidentemente claro que o estado do Amapá possui muitas limitações para demandar vagas em secretariado executivo no setor público para concurso público, sendo que quando há concursos poucas vagas são pleiteadas, uma vez que mesmo o mercado oferecendo vagas pouco é o reconhecimento e a valorização do profissional no mercado.

Sobre esta questão Graciane Leão (Bel em Secretariado) Comenta:

A sociedade amapaense é leiga quanto às atribuições do Secretario Executivo. Há muitas pessoas atuando no lugar do profissional de Secretário Executivo no mercado, uma vez que essas vagas deveriam ser ocupadas por profissionais com a devida qualificação, inclusive 
no setor público.

Sobre este assunto é importante ressaltar que além deste fato parte das organizações que querem contratar profissionais de secretariado não querem contratar profissionais como secretários executivos, más sim como auxiliar administrativo, assistentes, recepcionistas entre outros assim desvalorizando ainda mais a categoria. Este fato pode ser comprovado pelo gráfico 1 onde os dados comprovam que a maioria dos profissionais que realmente exerceram a função específica como secretario executivo exerceram nos estágios intermediados pela universidade durante 0 curso. A pesquisa comprovou a dificuldade para os profissionais em descobrir empresas que reconhecem e sabem o que faz e o que é um profissional da área secretarial.

Muitos entrevistados levantaram questionamentos de que o mercado Amapaense não está preparado para receber um profissional com um perfil ao qual a universidade forma com grandes competências, Isto caracteriza a iniciativa dos profissionais estarem buscando novas oportunidades. A partir deste ponto é que surge a importância de frisar 0 incentivo ao empreendedorismo, fomentar atividades, incentivar a capacitação individual/empresarial gerando assim alternativas que desenvolvam não somente 0 curso, más o estado e a região.

Em virtude de o cenário ser desfavorável aos profissionais de Secretariado Executivo, cabe aos mesmos fazerem uso de seus conhecimentos para gerar oportunidade em sua carreira profissional, buscando uma remuneração compatível com a sua graduação. $O$ que se torna interessante para os profissionais fazer negócios por oportunidade e não apenas por necessidade. Com um percentual de $53 \%$ a maioria dos egressos afirmou que não há boas expectativas de empregabilidade no estado do Amapá para o profissional de secretariado executivo, há demandas e vagas no mercado mais o mercado não tem estrutura para comportar profissionais capacitados por falta de reconhecimento da profissão e dos profissionais em questão.

Um dos fatores que contribui para a insuficiência de mercado de trabalho para os profissionais em Secretariado Executivo decorre da ausência de investimentos da própria Instituição de Ensino que não oferece aos profissionais do curso alternativas de empregabilidade voltadas para o empreendedorismo como um diferencial aos profissionais que não encontrarão no mercado satisfação e oportunidades em grandes empresas que reconheçam esses profissionais.

Por ser a mantenedora do curso, a Universidade deveria ser a maior incentivadora do cargo, abrindo concursos públicos e, desta forma, incentivando outras instituições públicas e/ou privadas. Além disto, incentivar o empreendedorismo e outras alternativas para geração de empregabilidade para que um profissional de secretariado executivo possa enfim, ter alternativas, oportunidades e características diferenciáveis que possam trazer satisfação na profissão dentro do estado do Amapá.

\section{Considerações Finais}

A inserção do empreendedorismo na área de secretariado vem ser uma nova forma de potencializar a profissão e demonstrar aos profissionais da área que é possível a constituição de seus próprios negócios na área. 0 tema empreendedorismo neste sentido vem ser mais uma nova abordagem na área de Secretariado Executivo, 0 que é decorrente de mudanças tecnológicas e econômicas que influenciam o mercado atual. 0 empreendedorismo vem surgir como mais uma nova vertente de atuação para os profissionais de secretariado, uma vez que estes almejam empreender na área secretarial e por este ser uma tendência a ser reforçada pelos profissionais da área no país já que buscam sempre estar criando e acompanhando novas tendências no mercado.

O apoio da universidade e do curso é fundamental para que desta forma a categoria possa através do empreendedorismo conquistar a valorização profissional almejada diante da possibilidade de atuação no mercado de trabalho, com o empreendedorismo, uma vez que há oportunidades de fazer seu próprio salário, havendo um nível de maior satisfação remunerativa, profissional ou pessoal colocando em prática seus conhecimentos e sair do paradigma de ser para todo o sempre somente um assessor, ou deixar de exercer a profissão, migrando para outras áreas de atuações, até mesmo no setor público desfavorecendo novas mudanças na profissão.

Para DURANTE E BARBOSA (2013,p.2): "O Secretário Executivo vem ressaltando seu perfil empreendedor e 
intra-empreendedor e, em consequência, constituindo seu próprio negócio." Dessa forma esta nova vertente é compreendida como o empreendedorismo secretarial para profissionais de Secretariado Executivo. Nesse sentido o Profissional de Secretariado entre as variadas possibilidades de atuações, vem ser um profissional de muitas habilidades e competências que agregam seu perfil, onde seu papel vai além de apenas atividades operacionais, tal quanto possa vir a tornar-se empreendedor assumindo função executiva.

A pesar da falta de percepção dos egressos em empreender na área secretarial em vista da carência de novas frentes de negócios na área, ficou comprovado que o curso de Secretariado Executivo é agente de formação de empreendedores. Após a análise dos dados obtidos foi possível compreender que estes possuem uma abrangente formação acadêmica que lhes da competências e habilidades para tornarem-se empreendedores de negócios. Portanto, esta pesquisa demonstra que ser empreendedor não é deixar de ser ou exercer a profissão, más apenas uma nova oportunidade profissional.

\section{Referências}

AZEVEDO, Ivanize; COSTA, Sylvia Ignácio Da. Secretária - um guia prático. 4 ed. São Paulo: SENAC, 2006.

BARROS, Fernanda Angélica de; KAFROUNI, Maria Ângela Sant'Anna. O ensino do empreendedorismo como complementação para o desenvolvimento do perfil profissional do jovem e seu primeiro emprego, 2014.

COSTA, Robson Antonio Tavares Da. Formação de empreendedores por meio de treinamento empresarial: "um estudo de caso com base nos dados disponibilizados pelo EMPRETEC Amapá - 2008" publicado em 2011.

DURANTE, Daniela Giareta; BARBOSA, Sheila Mara Costa. Secretariado Executivo e Empreendedorismo: Realidade ou utopia?, 2013.

DORNELAS, José Carlos Assis. Empreendedorismo: transformando idéias em negocios - Rio de Janeiro: Elsevier, 2001.

GARCIA, Edméa e D'ELIA, Maria Elizabete Silva. Secretária Executiva. São Paulo: IOB Thomson, 2005.

GIL, Antonio Carlos. Como elaborar projetos de pesquisa. 5. ed. São Paulo: Atlas, 2008.

GIL, Antônio Carlos. Como Elaborar Projetos de Pesquisa. $3^{\circ}$ ed. São Paulo: Atlas, 1996.

NATALENSE, M. L. C. Secretária Executiva: manual prático. São Paulo: IOB, 1995.

OTANI, Nilo; FIALHO, Francisco Antonio Pereira. TCC - Métodos e Técnicas, $2^{\mathrm{a}}$ edição revista Atualizada Florianópolis: Visual Books, 2011.

PORTELA, Keyla Christina Almeida; SCHUMACHER, Alexandre José. Ferramentas do Secretário Executivo. São Paulo: Viena, 2009.

PORTELA, K. C. A.; SCHUMACHER, A. J. Gestão secretarial: O desafio da visão holística. Cuiabá: Adeptus, 2009. v. I.

VILHENA, Camila Carolina Cunha; DIAS, Danusa de Oliveira. O Secretario Executivo Atuando Como Profissional Liberal: Novas Possibilidades No Mercado, 2014. 